\title{
Effect of Dietary Carotenoids on Reproducers of Amazon River Prawn Macrobrachium amazonicum. Part 2: External Coloration, Accumulation of Astaxanthin in Body Tissues and Pigment Stability in Feed
}

\author{
Daniel Pereira da Costa \\ Amapá State University - UEAP, Campus Lakes Territory, Av. Desidério Antônio \\ Coelho 470, Sete Mangueiras, Amapá, Amapá 68950-000, Brazil.
}

Tel: 55-37-98817-6804 E-mail: costazootecnia@gmail.com

ORCID: 0000-0002-8261-9899

\begin{abstract}
Claudiana de Lima Castilho
Rural Federal University of Amazonia - UFRA, Agricultural Sciences Institute, Estr. Principal da UFRA, 1970-2054, Curió Utinga, Belém, Pará 66610-770, Brazil.
\end{abstract}

Tel: 55-96-98116-9307 E-mail: costazootecnia@ gmail.com

ORCID: 0000-0002-9936-1273

Uclédia Roberta Alberto dos Santos

Laboratory of biomarkers of aquatic and immunochemical contamination LABCAI, Federal University of Santa Catarina - UFSC, Servidão do Caminho do Porto, Itacorubi, Florianópolis, Santa Catarina 88034-257, Brazil.

Tel: 55-48-3721-5470 E-mail: uclediaroberta@yahoo.com.br

ORCID: 0000-0002-9673-0184

\section{Tainára Cunha Gemaque}

Aquaculture Laboratory LAQUA (mariculture sector), Universidade Federal de Minas Gerais - UFMG, Av. Pres. Antônio Carlos 6627, Pampulha, Belo Horizonte - Minas Gerais 31270-901, Brazil. 
Tel: 55-37-98803-2898 E-mail: tainarapesca@gmail.com

ORCID: 0000-000 1-7348-6505

\title{
Leandro Fernandes Damasceno
}

Aquaculture and Fisheries Laboratory, Amapá Agroforestry Research Center, Brazilian Agricultural Research Corporation - EMBRAPA-Amapá, Rod. Juscelino Kubitschek 2, Jardim Equatorial, Macapá, Amapá 68903-012, Brazil.

Tel: 55-96-99903-8067 E-mail: leandro.damasceno@embrapa.br

ORCID: 0000-0002-7436-0071

\section{Jô de Farias Lima}

Aquaculture and Fisheries Laboratory, Amapá Agroforestry Research Center, Brazilian Agricultural Research Corporation - EMBRAPA-Amapá, Rod. Juscelino Kubitschek 2, Jardim Equatorial, Macapá, Amapá 68903-012, Brazil.

Tel: 55-96-99903-8067 E-mail: jo.lima@embrapa.br

ORCID: 0000-0001-6910-7672

Kleber Campos Miranda Filho (Corresponding author)

Aquaculture Laboratory (mariculture sector), Universidade Federal de Minas Gerais UFMG, Av. Pres. Antônio Carlos 6627, Pampulha, Belo Horizonte - Minas Gerais 31270-901, Brazil.

Tel: 55-31-98350-5167 E-mail: kleber08@gmail.com,kmiranda2010@ufmg.br ORCID: 0000-000 2-3026-4491

Received: January 7, 2021 Accepted: February 2, 2021 Published: February 19, 2021 doi:10.5296/jas.v9i2.18159 URL: https://doi.org/10.5296/jas.v9i2.18159

\begin{abstract}
The color is an important factor to distinguish the commercialized Amazon river prawns. The accumulation of pigments in the body can vary according to the prawn's diet. In this work, ethanolic extracts of "buriti" and annatto rich in pigments were obtained and tested comparatively with synthetic astaxanthin in the feeding of adults of Macrobrachium
\end{abstract}


amazonicum, together with a control group without pigments and a newly captured wild group. Levels of body pigments were measured using UV reflective spectroscopy and external staining by colorimetry. Differences were observed in the accumulation of astaxanthin in body tissues, differences in saturation between genders and that annatto extract has greater stability in the feed after water immersion $(\mathrm{P}<0.05)$. Further studies are recommended to verify the ideal dosage of natural pigments in relation to synthetic astaxanthin that benefits the productive development of prawns.

Keywords: astaxanthin, color, supplement, tissue accumulation

\section{Introduction}

The Amazon river prawn Macrobrachium amazonicum is a species of freshwater crustacean, diadromous, from South America (Fabri et al., 2019). Widely used for fishing in the northern region of the continent, in addition to aquaculture production with the rearing of juveniles captured in the wild and post larvae produced in the laboratory, extending their production to several locations in Brazil (Marques et al., 2012; Silva et al., 2017; Melo et al., 2020). Several researches have been directed to optimize their breeding in captivity, since it is a species with good acceptance by the consumer and good market value, relatively easy to grow and adapted to most growing conditions, including those integrated with other aquatic organisms (Flickinger et al., 2019; Dantas et al., 2020; Dutra et al., 2020; Lima et al., 2020).

The natural color of $M$. amazonicum when cooked is reddish (Costa and Miranda-Filho, 2020), a characteristic that can be observed in popular markets in northern Brazil where this prawn is commercialized. This color manifests itself due to the presence of astaxanthin, the main carotenoid pigment in the body of crustaceans (Wade et al., 2017). This carotenoid can be present in the natural foods of prawn such as zooplankton, be added in synthetic form or be converted by the xanthophyll and carotene present in foods of plant origin (Costa and Miranda-Filho, 2020). Maintaining adequate levels of body astaxanthin in crustaceans, in addition to improving the characteristic color for their commercialization, ensures that these reserves can supply its needs for functions such as retinoid and antioxidant (Aguirre-Hinojosa, et al., 2012; Daniel et al., 2017). The lack of this pigment can lead to diseases that compromise the normal development of crustaceans and increase mortality in captivity (Aguirre-Hinojosa et al., 2012; Niu et al., 2011). Astaxanthin stimulates growth, reproduction, larval development, it is present in both tissues and crustacean eggs and its deposition is stimulated both by the consumption of foods rich in pigments and by the darker growing environment (Tume et al., 2009; Tomas et al., 2019; Costa and Miranda-Filho, 2020).

In the Amazon region there are several foods rich in natural pigments. The advantages of using these supplements in animal feed are the availability and low cost compared to synthetic products, the possibility of organic or extractive production through sustainable management and the possibility of production by small farmers who already work with the capture and cultivation of prawn. As example, we can mention the "buriti" Mauritia flexuosa, natural source of beta-carotene and annatto Bixa sp. rich in bixin (Saini et al., 2015), both of which have already been studied as sources of carotenoids for animal feed (Dananjaya et al., 2017; Morais et al., 2017). 
Therefore, the present study aims to evaluate the potential of Amazon plant extracts and synthetic astaxanthin related to pigmentary deposition in various tissues and its influence on the external pigmentation of the shell in adults of $M$. amazonicum maintained in closed systems in comparison with wild and also between the sexes.

\section{Method}

\subsection{Animal Accommodation}

The prawns used in the study were obtained from fishermen in the Macapá region - AP $\left(00^{\circ} 02^{\prime} 20^{\prime \prime} \mathrm{N}, 51^{\circ} 03^{\prime} 59^{\prime \prime} \mathrm{W}\right)$, taken to the aquaculture and fisheries laboratory of the Amapá Agroforestry Research Center, EMBRAPA/Amapá.

The 36 prawns, divided into 3 repetitions, used to study the wild characteristics were readily analyzed according to the parameters of the study. The other 144 animals (in the treatments with experimental diets) were grown in twelve 60-liter tanks, consisting in four treatments with three replicates in each one.

Water quality parameters: temperature $\left(\mathrm{T}^{\circ} \mathrm{C}\right)$, hydrogenation potential $(\mathrm{pH})$, dissolved oxygen (DO), electrical conductivity (EC), total dissolved solids (TDS), salinity (SAL) and oxidation potential (PO) were measured with a U-5000 multiparameter probe (HORIBA ${ }^{\circledR}$, Kyoto, Japan). Total ammoniacal nitrogen (TA-N), nitrogen as nitrite $\left(\mathrm{NO}_{2}^{-}-\mathrm{N}\right)$ and alkalinity (ALC) were determined using colorimetric kits and HI 83200 multiparametric photometer (HANNA ${ }^{\circledR}$ Instruments, Woonsocket, Rhode Island, USA).

The water physicochemical variables presented the following average values: temperature $27.45^{\circ} \mathrm{C}( \pm 0.47) ; \mathrm{pH} 8.5( \pm 0.42)$; dissolved oxygen $7.06 \mathrm{mg} / \mathrm{L}( \pm 1.14)$; electrical conductivity $0.45 \mathrm{mS} / \mathrm{cm}( \pm 0.04)$; total dissolved solids $0.30 \mathrm{mg} / \mathrm{L}( \pm 0.03)$; salinity $0.2 \%$; total ammonia $0.12 \mathrm{mg} / \mathrm{L}( \pm 0.04)$; nitrite $0.09 \mathrm{mg} / \mathrm{L}( \pm 0.02)$; oxidation potential $205.45 \mathrm{mV}$ $( \pm 26.96)$ and alkalinity $43.49 \mathrm{mg} / \mathrm{L} \mathrm{CaCO}_{3}( \pm 9.59)$.

\subsection{Experimental Diets}

In order to prepare the ethanol extracts, $100 \mathrm{~g}$ of each fruit ("buriti" and annatto) were crushed in a blender together with $96^{\circ} \mathrm{GL}$ ethanol, rested for $24 \mathrm{~h}$ at $30^{\circ} \mathrm{C}$ to extract the pigments. The extracts were separated from the fibrous residue by filter and their volume corrected for $100 \mathrm{~mL}$. In the case of the synthetic astaxanthin, $2 \mathrm{~g}$ of the product were diluted in water $(10 \mathrm{~mL})$ and the rest of the volume completed with the same ethanol to be equal to the other extracts. Only the ethanol and water solution were reserved for the control group. The extracts were included in the diets by spraying them on the surface of the extruded commercial feed pellets ( $38 \%$ Crude Protein) and dried for $8 \mathrm{~h}$ in an oven at $60^{\circ} \mathrm{C}$. The ration was supplied in the amount of $2 \mathrm{~g}$ per replica daily (3.3\% of live weight) divided into two rations, being $0.5 \mathrm{~g}$ in the morning (10:00 a.m.) and $1.5 \mathrm{~g}$ in the evening (06:00 p.m.).

\subsection{Experimental Test}

The experiment was designed in randomized blocks, containing five treatments with three replications and analyzed in a $5 \times 2$ factorial scheme (five treatments and two sexes). 180 
prawns were distributed in five groups containing 4 males $(6.08 \pm 1.96 \mathrm{~g})$ and 8 females $(4.55$ $\pm 1.03 \mathrm{~g}$ ) according to the diet: 1 ) animals submitted to the control diet without the inclusion of pigments (CONT); 2) animals submitted to a diet containing natural extract of "buriti" that has beta-carotene as the main pigment (BUR); 3) animals submitted to the diet with natural extract of "annatto", including bixin as the main pigment (URU); 4) animals submitted to the diet with synthetic astaxanthin (ASTX) and 5) animals that were not submitted to any artificial diet (NATURAL). Thus, one group representing the wild diet, two groups with a low concentration of pigments and two groups with a high concentration of pigments, as described in Table 1.

\subsection{Pigment in the Tissue}

For the analysis of pigment concentration, one male and one female from each repetition $(\mathrm{n}=$ 6) were randomly sampled and dissected to separate the tissues to be analyzed (stomach, hepatopancreas, gonads, muscle, shell and the rest of the cephalothorax and abdomen).

Table 1. Concentration of pigments (DM) of the experimental diets of Macrobrachium amazonicum

\begin{tabular}{ccccc}
\hline Carotenoids & \multicolumn{4}{c}{ Experimental Diets } \\
\cline { 2 - 5 } & CONT & BUR & URU & ASTX \\
\hline$\beta$-carotene (mg/kg) & 15.71 & 38.09 & - & - \\
Bixin (mg/kg) & - & - & 289.71 & - \\
Astaxanthin (mg/kg) & - & - & - & 197.45 \\
\hline
\end{tabular}

$\mathrm{DM}=$ Dry Matter; CONT = control; BUR = "buriti" extract; URU = "annatto" extract; ASTX $=$ syntetic astaxanthin.

The prawn tissues were macerated in $96^{\circ} \mathrm{GL}$ ethanol and analyzed in a UV SP220 spectrophotometer (Bioespectro $^{\circledR}$, Curitiba-PR, Brazil), at a wavelength of $478 \mathrm{~nm}$ of absorbance (ABS) of astaxanthin and absorption coefficient E1\% $1 \mathrm{~cm} 2100$ for the calculation of the concentration astaxanthin $(\mathrm{mg} / \mathrm{Kg})$ contained in the tissue (ACT). For the diets (Table 1), the same technique as the ASTX diet was used with the same values for the animals, for CONT and BUR, $452 \mathrm{~nm} \mathrm{ABS}$ and E1\% 1 cm 2620 absorption coefficient and in

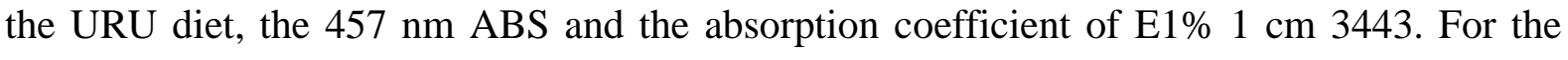
determination of retinol, ABS was used at $325 \mathrm{~nm}$ and the absorption coefficient E1\% $1 \mathrm{~cm}$ 1780, as in the methodology described by Dias et al. (2010). The calculation was performed using the Rodriguez-Amaya (2001) methodology and from Rodriguez-Amaya \& Kimura (2004), the following equation (1):

$$
[\mathrm{mg} \text { of pigment } / \mathrm{Kg}]=(\mathrm{ABS} \times \mathrm{DF} \times \mathrm{V}) /(\mathrm{CA} \times(\mathrm{g}))(1)
$$


Where:

$\mathrm{ABS}=$ absorbance of the pigment in the ethanol solution $(\mathrm{nm})$

$\mathrm{DF}=$ dilution factor $(=1,000,000)$

$\mathrm{V}=$ volume of the solution

$\mathrm{CA}=\mathrm{E} 1 \% 1 \mathrm{~cm}$ pigment absorption coefficient in ethanol

$\mathrm{g}=$ grams of sample used

\subsection{Color Analysis}

The colorimetric analysis of the prawns' body surface was performed by reflective spectroscopy, using a digital colorimeter (Minolta Color Reader CR-400), according to the CIE system $\mathrm{L} * \mathrm{C} * \mathrm{~h}$, where $\mathrm{L}=$ luminosity, $\mathrm{C}=$ saturation and $\mathrm{h}=$ hue.

The readings were taken on the shell at five points: on the cephalothorax on the dorsal part behind the rostrum and lateral on the hepatic region, between the first and the second somite in the abdominal region of the pleura and in the dorsal region, and in the dorsal part of the telson. Sampled after cooking for 1 minute at $100^{\circ} \mathrm{C}$ and averaged for comparison.

\subsection{Pigment Stability in the Ration}

Homogenized samples of the same experimental feed (provided to the prawns) were collected, crushed into porcelain grains bowls, weighed $(1.0 \mathrm{~g})$ and analyzed in quadruplicate by the carotenoid determination methodology previously described. The prepared material was immersed in test tubes with $10 \mathrm{~mL}$ of distilled water solution with salinity of $0.2 \%$, $\mathrm{pH} 8.5$ (corrected with $\mathrm{CaCO}_{3}$ ) and $27.5^{\circ} \mathrm{C}$ for $0,60,120$ and 240 minutes in thermostatic bath under agitation.

\subsection{Statistical Analysis}

The data were initially submitted to the Shapiro-Wilk normality test. ANOVA with Duncan test were used for astaxanthin concentration variables, Kruskal-Wallis test for color variables, Friedman test for comparing astaxanthin averages between tissues and polynomial regression for pigment stability tests in the feed, all with significance level of 5\%. Statistical analysis was performed using the INFOSTAT program, version 2019 (Casanoves et al., 2012).

\section{Results}

\subsection{Pigment Analysis in the Tissue}

The results for tissue pigmentation are shown in Table 1A (Appendix). As observed, astaxanthin in the abdomen in the ASTX treatment was similar to the NATURAL group and superior to the other treatments $(\mathrm{p}<0.05)$, while in the cephalothorax and shell these two treatments had a better result than the other groups $(\mathrm{p}<0.05)$. In hepatopancreas, the ASTX treatment performed better than all other treatments $(\mathrm{p}<0.05)$, while in the gonads, it was superior to the BUR and NATURAL groups $(p<0.05)$. Between genders, males had higher values of astaxanthin in the abdomen and shell and females in the gonads $(\mathrm{p}<0.05)$. 
In males, the abdomen had a level of astaxanthin similar to the NATURAL group in the URU and ASTX treatments. In the cephalothorax and stomach, the NATURAL group obtained a better result than CONTROL $(\mathrm{p}<0.05)$, while in hepatopancreas, the ASTX group was superior to CONTROL ( $\mathrm{p}<0.05$ ). The ASTX treatment and the NATURAL group had superior results compared to the BUR treatment in the shell $(\mathrm{p}<0.05)$.

In females, the ASTX and NATURAL treatments showed a better result in the abdomen than the other treatments $(\mathrm{p}<0.05)$, while in the cephalothorax, ASTX was superior to the other treatments and the NATURAL group was superior to CONTROL ( $\mathrm{p}<0.05)$. In hepatopancreas and in the shell, ASTX and NATURAL also had a better result than the other treatments, however, in the ASTX shell, it was also superior to NATURAL group ( $\mathrm{p}<0.05)$. In the gonads, NATURAL group performed better, while ASTX treatment was superior to CONTROL $(\mathrm{p}<0.05)$.

Among the tissues, the stomach showed a higher rate of pigment accumulation followed by gonads and hepatopancreas. The muscle had the lowest accumulations of astaxanthin $(\mathrm{p}<0.05)$. However, in males, the shell accumulated more pigment than the gonads $(p<0.05)$, and in females the levels of gonads and stomachs had similar levels $(\mathrm{p}<0.05)$.

\subsection{Color Analysis}

A significant difference was observed only between genders in $\mathrm{C}$, with males having greater color saturation than females ( $\mathrm{p}<0.05$ ) according to Table 2A (Appendix).

\subsection{Analysis of Pigment Stability in the Ration}

As can be seen in figure 1, annatto extract has greater stability in the diet from 60 to 240 minutes after immersion.

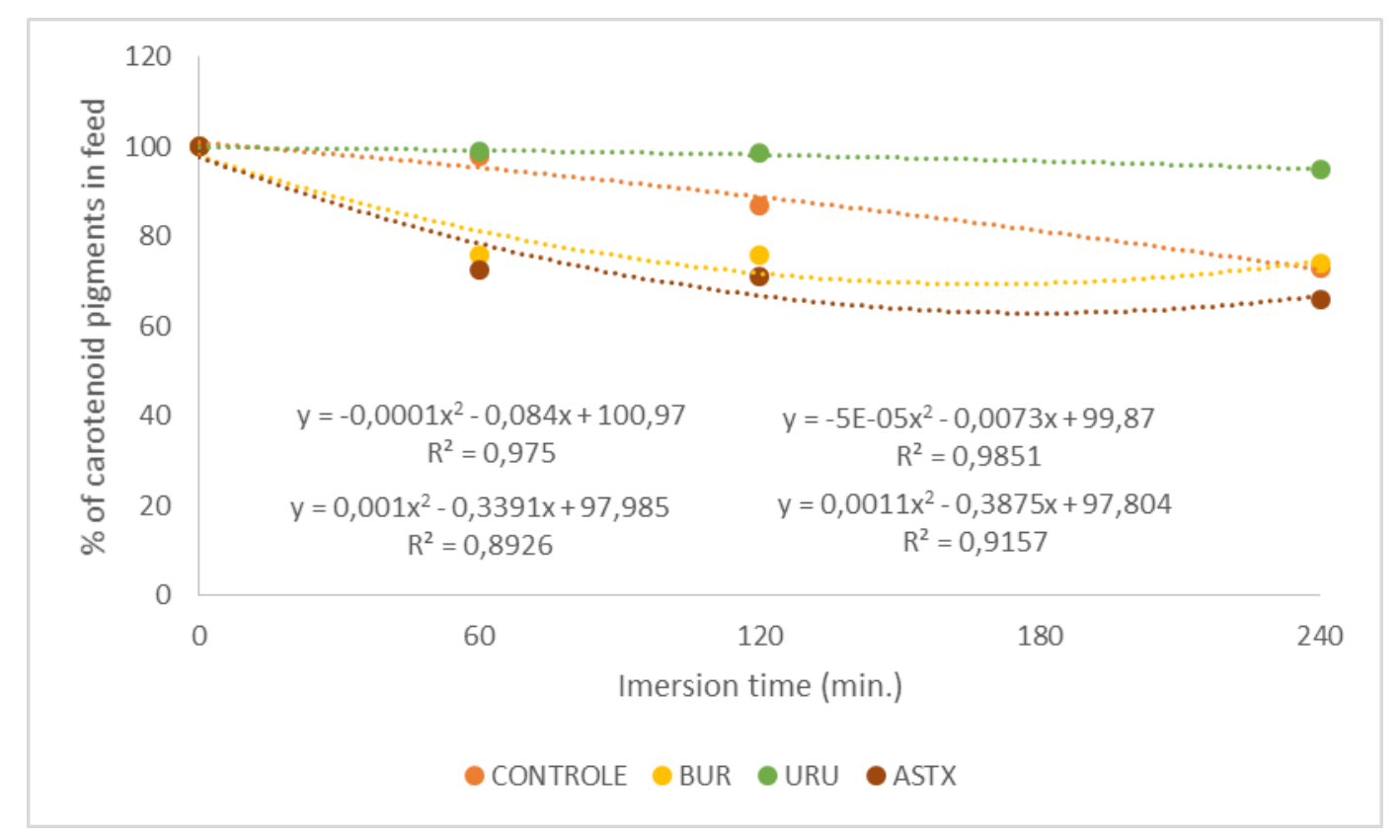

Figure 1. Pigment stability in prawn feed after immersion in water. $\mathrm{CONTROL}=$ no pigment 
added, BUR = "buriti" extract, URU = annatto extract, ASTX = syntetic astaxanthin, NATURAL $=$ wild diet.

\section{Discussion}

The use of synthetic astaxanthin was more efficient in the pigmentation of several body tissues except for the musculature in which the pigment levels were below the other tissues and remained stable despite the quantitative and qualitative variations of the extracts.

Although it has shown intermediate responses between the highest and lowest levels of astaxanthin in tissues, annatto extract can be a potential supplement to replace synthetic astaxanthin (Fries et al., 2014; Safari and Atash, 2015; Dananjaya et al., 2017). However, more studies are demanded to determine the amount needed to supply the requirement for pigment by $M$. amazonicum and the time of use that allows its metabolization. As precursor, the amount of annatto extract added is generally higher than astaxanthin, since there is a metabolic cost for conversion of the precursor carotenoid, such as the energy expenditure in the oxidation process carried out in the organism (Güroy et al., 2012; Costa and Miranda-Filho, 2020). In addition to the pigment accumulation and color manifestation, the reproductive function can be influenced by the use of the pigment related to female fertility and larval survival (Ribeiro et al., 2001; Tizkar et al., 2014).

"Buriti" extract had a low pigment yield in its extraction, probably because of the lack of heat treatment during extraction with commercial ethanol, as recommended by Ribeiro et al. (2010). However, its use was sufficient in some tissues to guarantee a minimum pigment supply and comparable to other treatments with higher concentration. Probably because of the use of flavonoids with antioxidant function present in "buriti" and highly soluble in ethanol (Moura-Filho et al., 2017), which could contribute to the demand for antioxidants, having a synergistic effect with carotenoids in this function (Fattore et al., 2016). The preparation of feed from "buriti" can contribute to the accumulation of body pigments, since the presence of beta-carotene is beneficial for crustaceans (Madhumathi and Rengasamy, 2011).

In addition to the use of "buriti" oil in the feed of M. amazonicum to provide greater final biomass in cultivation (Guerra et al., 2019), the study of the necessary quantity can determine the ways of its use in the crustacean feeding.

There was no variation in the concentration of pigments in the gonads of males and in the stomachs of females. In the case of males, less need for carotenoid in the formation of gametes was observed, although it is essential and can be stimulated by the consumption of astaxanthin precursors (Braga et al., 2013). In female gonads, the presence of developing eggs can influence the amount of pigment, since the deposition of pigments in crustacean eggs is essential for their perfect development (Maulana et al., 2017; Wang et al., 2018). In the case of stomachs, they can serve as a deposition site for body pigment, however previous studies have not addressed the quantification of pigments in gastric tissue. As the body structure of $M$. amazonicum is generally transparent, the dark color of the stomach and hepatopancreas are visually noticed. 
Males showed greater pigment accumulation in the abdomen and shell, probably due to the lower demand for pigment for reproduction in relation to females, since in gonads the volume of pigment in females is greater than in males. In this sense, astaxanthin stored in hepatopancreas lipocarotenoproteins is transported by vitellogenin and accumulates in the eggs forming inside the gonads (Corral-Rosales et al., 2019).

The tissues of $M$. amazonicum have heterogeneous amounts of pigments, and this accumulation is influenced by the function of the pigment in a given tissue, which can be related to mimicry, protection of gametes, or reserve material (Wade et al., 2017). Due to the high concentration of pigments, some organs of $M$. amazonicum are visible in the cephalothorax, being greenish in the gonads and brown, gray or black in the other organs. The rest of the body is predominantly transparent with some spots with chromatophores with colors similar to those of the organs.

According to Babin et al. (2019), the accumulation of carotenoids in crustaceans depends on their environmental availability (for animal consumption) and individual characteristics. According to these authors, their main uses in metabolism are immunological (processes of resistance and tolerance), in addition to survival strategies related to aging.

Despite the quantitative differences in pigment in the internal tissues, the treatments did not influence the external color of the prawn, which remained homogeneous. This shows that surface color does not reflect the body quantity of astaxanthin and does not serve to predict product quality related to carotenoid content. According to Aréchiga-Palomera et al. (2018), external coloring is related to the environment due to the mimicry relationship in which crustaceans intensify their pigmentation to be confused with the darker pond, or decrease in a lighter pond, as observed in Macrobrachium tenellum. As there are differences between the sexes in the concentration of astaxanthin in the shell and in the abdomen, where the color measurement was located, in this case, the data may have some relationship.

The color difference can determine a greater preference for crustaceans' consumers (Parisenti et al., 2011), giving advantage to males. Also associated with the fact that the male prawns are larger than the female, there is a greater demand for males in the local trade, according to local fishermen. But the size difference between males, according to morphotypes, must also be considered, which is determined by population dynamics in which it is not possible to have uniformity in the size of the entire male population (Pantaleão et al., 2014).

In the pigment stability test, the annatto extract performed better than the others. This greater stability is a factor that makes it interesting to use this supplement in the feed for aquaculture use. According to Tsimidou and Tsatsaroni (1993), the main factors that influence the stability of carotenoid pigments in aqueous media are light intensity, $\mathrm{pH}$ and temperature. As in this work these conditions were controlled, the water solubility can be pointed out as the main determinant for the test result. Since xanthophylls (such as astaxanthin) have a greater number of oxygen atoms, they tend to establish a greater number of hydrogen and hydroperoxide bonds, which may increase their affinity for water (Ramakrishnan and Francis, 1979), while the polygenic chain of bixin makes it highly hydrophobic, preventing its solubility in aqueous medium (Jahangiri et al., 2018). 


\section{Macrothink}

Journal of Agricultural Studies

ISSN 2166-0379

2021, Vol. 9, No. 2

Future studies should explore the effectiveness, concentration and application of natural pigments and synthetic astaxanthin for $M$. amazonicum and their role in growth, reproduction, pigmentation and enrichment of the final product. Since pigment-rich foods are important for the growth and survival of prawn of the genus Macrobrachium (such as Macrobrachium rosenbergii) (Zelaty et al., 2016A; Zelaty et al., 2016B), and directly affect the immunity of invertebrates in general (Tan et al., 2020), the use of these and other resources of natural origin can facilitate local producers to prepare and use these pigments in a sustainable and economical way.

\section{Conclusions}

The use of different carotenoid pigments in the diet of Amazonian river prawn $M$ amazonicum resulted in different accumulation of astaxanthin in the body tissues of the species. Biologically, this build-up can improve its reproduction. In addition, the carotenoid content may be more appealing to human nutrition. The shell external color is different between the sexes, being more saturated in males than females. The annatto extract has the greatest stability in the ration when immersed in water for a period of 60 to 240 minutes.

\section{References}

Aguirre-Hinojosa, E., Piña-Valdez, P., Garza-Aguirre. M. C., Guzmán-Ramirez, L. D., Montoya-Olvera, R., Torres-Quiroga, J., \& Nieves-Soto, M. (2012). The effect of xantophylls of marigold Tagetes erecta L. flower on Astaxanthin accumulation and survival of white shrimp postlarvae Litopenaeus vannamei (Boone, 1931). Revista Mexicana de Ingenheria Química, 11, 249-257. (in Spanish)

Aréchiga-Palomera, M. A., Vega-Villasante, F., Montoya-Martínez, C., Mendoza-Gonzáles, A., \& Badillo-Zapata, D. (2018). Background color effect on the pigmentation of prawn Macrobrachium tenellum. Latin American Journal of Aquatic Research, 46(3), 610-614. https://doi.org/10.3856/vol46-issue3-fulltext-16

Babin, A., Moreau, J., \& Moret, Y. (2019). Storage of carotenoids in crustaceans as an adaptation to modulate immunopathology and optimize immunological and life-time strategies. BioEssays, 41(11), 1800254. https://doi.org/10.1002/bies.201800254

Braga, A. L., Lopes, D. L. A., Poersch, L. H. \& Wasielesky-Jr, W. (2013). Spermatophore and sperm quality of the pink shrimp Farfantepenaeus paulensis fed with fresh food supplemented with pollen and paprika. Aquaculture, 380-383, 29-32. https://doi.org/10.1016/j.aquaculture.2012.11.030

Casanoves, F., Balzarini, M. G., Di Rienzo, J. A., Gonzalez, L., Tablada, M., \& Robledo, C. W. (2012). InfoStat. User Manual, Córdoba, Argentina, 40 p.

Corral-Rosales, C., Ricque-Marie, D., Cruz-Suarez, L. E., Arjona, D., \& Palacios, E. (2019). Fatty acids, steroids, phenolic compounds, and carotenoid changes in response to dietary inclusion of Ulva clathrata in shrimp Litopenaeus vannamei broodstock. Journal of Applied Phycology, 31, 4009-4020. https://doi.org/10.1007/s10811-019-01829-2 
Costa, D. P., \& Miranda-Filho, K. C. (2020) The use of carotenoid pigments as food aditives for aquatic organisms and their functional roles. Reviews in Aquaculture, 12(3), 1567-1578. https://doi.org/10.1111/raq.12398

Dananjaya, S. H. S., Munasinghe, D. M., Ariyaratne, H. B. S., Lee, J., \& De Zoysa, M. (2017). Natural bixin as a potential carotenoid for enhancing pigmentation and colour in goldfish (Carassius auratus) Aquaculture Nutrition, 23, 255-263. https://doi.org/10.1111/anu.12387

Daniel, N., Sivaramakrishnan, T., Subramaniyan, S., Faizullah, M. M., \& Fernando, H. (2017) Application of carotenoids on coloration of aquatic animals. International Journal of Fisheries and Aquaculture, 2(1), 1-7.

Dantas, D. P., Flickinger, D. L., Costa, G. A., Batlouni, S. R., Moares-Valenti, P., \& Valenti, W. C. (2020). Technical feasibility of integrative Amazon river prawn culture during first phase of tambaqui grow-out in stagnant ponds using nutrient-rich water. Aquaculture, 516, 734611. https://doi.org/10.1016/j.aquaculture.2019.734611

Dias, S. S., Godoy, R. L. O., Pacheco, S., Reis, R. C. S., \& Schutz, D. F. (2010). Obtaining an analytical standard of retinol from bovine liver via high-performance liquid chromatography on an analytical scale Universidade Federal Rural do Rio de Janeiro, Embrapa Agroindústria de Alimentos. (in Portuguese)

Dutra, F. M., Alab, J. H. C., Gomes, M. K. C., Furtado, P. S., Valenti, W. C., \& Ballester, E. L. C. (2019). Nitrate acute toxicity to pos larvae and juvenile of Macrobrachium amazonicum $\begin{array}{llll}\text { (Heller 1862). } & \text { Chemosphere, } & 2019, & \end{array}$ https://doi.org/10.1016/j.chemosphere.2019.125229

Fabri, L. M., Lucena, M. N., Garçon, D. P., Moraes, C. M., McNamara, J. C., \& Leone, F. A. (2019). Kinetic characterization of the gill $\left(\mathrm{Na}^{+}, \mathrm{K}^{+}\right)$ATPase in a holometric population of the diadromous Amazon River shrimp Macrobrachium amazonicum (Decapoda, Palaemonidae). Comparative of Biochemistry and Physiology B, 227, 64-74. https://doi.org/10.1016/j.cbpb.2018.09.004

Fattore, M., Montesano, D., Pagano, E., Teta, R., Borrelli, F., Mangoni, A., Seccia, S., \& Albrizio, S. (2016). Carotenoid and flavonoid profile and antioxidant activity in "Pomodorino vesuviano" tomatoes. Journal of Food Composition Analysis, 53, 61-68. https://doi.org/10.1016/j.jfca.2016.08.008

Flickinger, D. L., Costa, G. A., Dantas, D. P., Moraes-Valenti, P., \& Valenti, W. C. (2019). The budget of nitrogen in the grow-out of the Amazon river prawn (Macrobrachium amazonicum Heller) and tambaqui (Colossoma macropomum Cuvier) farmed in monoculture and integrated multitrophic aquaculture systems. Aquaculture Research, 50(11), 3444-3461. https://doi.org/10.1111/are.14304

Fries, E. M., Bitarello, A. C., Zaminhan, M., Signor, A., Feiden, A., \& Boscolo, W. R. (2014). Annatto in diets for Carassius auratus fingerlings: Productive performance and skin pigmentation. Semina: Ciências Agrárias, 35, 3401-3414. (in Portuguese). 
https://doi.org/10.5433/1679-0359.2014v35n6p3401

Guerra, J. A., Nunes, C. A. R., Lima, J. A., Sousa, G. R., Freitas, I. S., Carvalho. L. S., ... Amorim, T. S. (2019). Buriti oil (Mauritia flexuosa) in the food of the shrimp Macrobrachium amazonicum (Heller, 1862). Revista Brasileira de Engenharia de Pesca, 12(1), 10-16. (in Portuguese). https://doi.org/10.18817/repesca.v12i1.1812

Güroy, B., Sahin, I., Mantoglu, S., \& Kayali, S. (2012). Spirulina as a natural carotenoid source on growth, pigmentation and reproductive performance of yellow tail cichlid Pseudotropheus acei. Aquaculture International, 20, 869-878. https://doi.org/10.1007/s10499-012-9512-x

Jahangiri, A., Møller, A. H., Danielsen, M., Madsen, B., Joernsgaard, B., Vaerbak, S., ... Dalsgaard, T. K. (2018). Hydrophilization of bixin by lipase-catalyzed transesterification with sorbitol. Food Chemistry, 268, 203-209. https://doi.org/10.1016/j.foodchem.2018.06.085

Lima, J. F., Lobo, E. T., Bastos, A. M., \& Duarte, S. S. (2020). Nitrate level safety to Amazon river shrimp juveniles. Environmental Science Pollution Research, 27, 4546-4550. https://doi.org/10.1007/s11356-019-07033-6

Madhumathi, M., \& Rengasamy, R. (2011). Antioxidant status of Penaeus monodon fed with Dunaliella salina supplemented diet and resistance against WSSV. International Journal of Engineering Science and Technology, 3(10), 7249-7259

Marques, H. L. A, Barros. H. P., Mallasen, M., Boock, M. V., \& Valenti, P. M. C. M. (2012). Influence of stocking densities in the nursery phase on the growth of Macrobrachium amazonicum reared in net pens. Aquaculture, 358-359, 240-245. https://doi.org/10.1016/j.aquaculture.2012.06.011

Maulana, F., Arfah, H., Istifarini, M., \& Satiawati, M. (2017). Supplementation of astaxanthin and vitamin $\mathrm{E}$ in feed on the development of gonads Pacific white shrimp broodstock. Jurnal Akuakultur Indonesia, 16(2), 124-135. https://doi.org/10.19027/jai.16.2.124-135

Melo, O. A., Silva, L. M. A., Souza, P. H. C., Silva, S. L. F., Lima, J. F., Santos-Junior, L. C. F., Fernandes, L. G., Silva, K. C. A., \& Cintra, I. H. A. (2020). Profitability and sustainable use of traps for Amazon shrimp (Macrobrachium amazonicum) from the Amazon River. Journal of Agricultural Studies, 8(3), 616-632. https://doi.org/10.5296/jas.v8i3.16755

Morais, J. S., Bezzerra, L. R., Silva, A. M. A., Araújo, M. J., Oliveira, R. L., Edvan, R. L., Torreão, J. N. C., \& Lanna, D. P. D. (2017). Production, composition, fatty acid profile and sensory analysis of goats fed buriti oil. Journal of Animal Science, 95(1), 395-406. https://doi.org/10.2527/jas.2016.0746

Moura-Filho, J. M., Nagai, L. Y., Nascimento, L. C. S., Cavalcante-Neto, A. A., \& Penna, A. L. B. (2017). Determination of the optimum solvent for extracting the phenolic compounds from the buriti fruit. Brazilian Journal of Food Research, 8(3), 22-28. (in Portuguese)

Niu, J., Tian, L-X., Lin, H. Z., \& Liu, Y. (2011). Carotenoids in aquaculture, an overview. Journal of Animal Science Biotechnology, 2, 44-58. 
Pantaleão, J. A. F., Hirose, G. L., \& Costa, R. C. (2014). Occurrence of male morphotypes of Macrobrachium amazonicum (Caridea, Palaemonidae) in a population with an entirely freshwater life cycle. Brazilian Journal of Biology, 74(3), 223-232. https://doi.org/10.1590/1519-6984.03713

Parisenti, J., Beirão, L. H., Tramonte, V. L. C. G., Ourique, F., Brito, C. C. S., \& Moreira, C. C. (2011). Preference ranking of color in raw and cooked shrimps. International Journal Food Science and Technology, 46(12), 2558-2561. https://doi.org/10.1111/j.1365-2621.2011.02781.x

Ramakrishnan, T. V., \& Francis, F. J. (1979). Stability of carotenoids in model aqueous systems. Journal of Food Quality, 2(3), 177-189. https://doi.org/10.1111/j.1745-4557.1979.tb00667.x

Ribeiro, B. D., Nascimento, R. F., Barreto, D. W., Coelho, M. A. Z., \& Freitas, S. P. (2010). An ethanol-based process to simultaneously extract and fractionate carotenoids from Mauritia flexuosa L. Pulp. Revista Brasileira de Fruticultura, 32(3), 657-663. https://doi.org/10.1590/S0100-29452010005000099

Ribeiro, E. A., Genofre, G. C., \& McNamara, J. C. (2001). Identification and quantification of carotenoid pigments during the embryonic development of the freshwater shrimp Macrobrachium olfersii (Crustacea, Decapoda). Marine and Freshwater Behaviour Physiology, 34, 105-116. https://doi.org/10.1080/10236240109379063

Rodriguez-Amaya, D. B. (2001). A guide to carotenoid analysis in foods. Washington: International Life Sciences Institute Press. 64 p.

Rodriguez-Amaya, D. B., \& Kimura, M. (2004). Handbook for carotenoid analysis. (HarvestPlus Technical Monograph, 2). 58 p.

Safari, O., \& Atash, M. M. S. (2015). The effects of dietary supplement of annatto (Bixa orellana) seed meal on blood carotenoid content and fillet color stability in rainbow trout (Oncorhynchus mykiss). Aquaculture, 275-281. https://doi.org/10.1016/j.aquaculture.2014.12.012

Saini, R. K., Nile, S. H., \& Park, S. W. (2015). Carotenoids from fruits and vegetables: Chemistry, analysis, occurrence, bioavailability, and biological activities. Food Research International, 76(3), 735-750. https://doi.org/10.1016/j.foodres.2015.07.047

Silva, R. C., Jacobucci, G. B., \& Mossolin, E. C., (2017). Reproductive biology of Macrobrachium amazonicum (Heller, 1862) (Decapoda: Palaemonidae) in a reservoir situated in Minas Gerais state, Southeastern Brazil. Latin American Journal of Aquatic Research, 45(4), 776-786. https://doi.org/10.3856/vol45-issue4-fulltext-13

Tan, K., Zhang, H., Lim, L-S., Ma, H., Li, S., \& Zheng, H. (2020). Roles of carotenoids in invertebrate immunology. Frontiers in Immunology, 10(3041), 1-10. https://doi.org/10.3389/fimmu.2019.03041

Tizkar, B., Seidavi, A., Ponce-Palafox, J. T., \& Parastoo, P. (2014). The effect of astaxanthin 
on resistance of juvenile prawns Macrobrachium nipponense (Decapoda: Palaemonidae) to physical and chemical stress. International Journal of Tropical Biology, 62(4), 1331-1341. https://doi.org/10.15517/rbt.v62i4.13057

Tomas, A. L., Sganga, D. E., \& Greco, L. S. L. (2019). Effect of background color and shelters on female pigmentation in the ornamental red cherry shrimp Neocaridina davidi (Caridae, Atyidae). Journal of World Aquaculture Society, 2019, 1-13. https://doi.org/10.1111/jwas.12660

Tsimidou, M., \& Tsatsaroni, E. (1993). Stability of saffron pigments in aqueous extracts. $\begin{array}{llrr}\text { Journal of } & \text { Food } & \text { Science, } & \text { 58(5), }\end{array}$ https://doi.org/10.1111/j.1365-2621.1993.tb06116.x

Tume, R., Sikes, A. B. S., Tabrett, S. B. S., Smith, D. B. S., \& Sellars, M. (2009). Add value to shrimp harvests: Darken environment to enhance shrimp color. Global Aquaculture Advocate - Health and Walfare - Tuesday $01 \quad$ September 2009 <aquaculturealliance.org/advocate/add-value-to-shrimp-harvests-darken-environment-to-enha nce-shrimp-color/>

Wade, N. M., Gabaudan, J., \& Glencross, B. D. (2017). A review of carotenoid utilization and function in crustacean aquaculture. Reviews in Aquaculture, 9(2), 141-156. https://doi.org/10.1111/raq.12109

Wang. W., Ishikawa, M., Koshio, S., Yokoyama, S., Dawood, M. A. O., \& Zhang, Y. (2018). Effect of dietary astaxanthin supplementation on survival, growth and stress resistance in larval and post larval Kuruma shrimp, Marsupenaeus japonicus. Aquaculture Research, 49(6), 2225-2232. https://doi.org/10.1111/are.13679

Zelaty, A. H., Murthy, H. S., Nazarkadeh, A., Ahmadiyam, S. H., Meshram, S. J., Amin, A., \& Swain, H. S. (2016A). Influence of dietary supplementation of carotenoid (diacetate of lutein-mesozeaxanthin) on growth performance, biochemical body composition in freshwater prawn, Macrobrachium rosenbergii. Journal of Aquatic Marine Biology, 4(2), 00078. https://doi.org/10.15406/jamb.2016.04.00078

Zelaty, A. H., Murthy, H. S., Priyadarshini, N., Meshram. S. J., \& Amin, A., (2016B). Effect of dietary marigold oleoresin on growth performance, survival, body composition and water quality changes during Macrobrachium rosenbergii culture. Journal of Experimental Zoology India, 19(2), 785-791. 


\section{Appendix}

Table 1A. Tissue astaxanthin levels (mean and standard deviation) in Macrobrachium amazonicum fed with different sources of carotenoid pigments

\begin{tabular}{|c|c|c|c|c|c|c|c|c|}
\hline \multicolumn{2}{|c|}{ Groups } & \multicolumn{7}{|c|}{ Body tissue } \\
\hline & & Abdomen & Cephalothorax & Muscle & Hepatopancreas & Stomach & Shell & Gonad \\
\hline \multirow{7}{*}{ Total } & CONTROL & $4.89 \pm 2.01^{\mathrm{a}}$ & $8.34 \pm 5.66^{\mathrm{a}}$ & $1.69 \pm 0.36$ & $9.17 \pm 7.01^{\mathrm{a}}$ & $\begin{array}{l}33.35 \pm \\
19.53\end{array}$ & $11.85 \pm 7.75^{\mathrm{a}}$ & $\begin{array}{l}20.90 \pm \\
15.17^{\mathrm{ab}}\end{array}$ \\
\hline & BUR & $5.06 \pm 2.02^{\mathrm{a}}$ & $11.61 \pm 3.71^{\mathrm{a}}$ & $1.09 \pm 0.32$ & $13.30 \pm 5.7^{\mathrm{a}}$ & $\begin{array}{l}44.36 \pm \\
25.03\end{array}$ & $11.40 \pm 5.20^{\mathrm{a}}$ & $16.59 \pm 6.72^{\mathrm{a}}$ \\
\hline & URU & $6.23 \pm 4.32^{\mathrm{ab}}$ & $12.81 \pm 5.31^{\mathrm{a}}$ & $1.25 \pm 0.96$ & $14.76 \pm 7.23^{\mathrm{a}}$ & $\begin{array}{c}50.81 \pm \\
10.46\end{array}$ & $13.36 \pm 10.46^{\mathrm{a}}$ & $\begin{array}{c}20.21 \pm \\
10.70^{\mathrm{ab}}\end{array}$ \\
\hline & ASTX & $11.94 \pm 2.54^{\mathrm{c}}$ & $22.65 \pm 2.42^{\mathrm{b}}$ & $2.14 \pm 1.21$ & $42.84 \pm 28.09^{b}$ & $59.61 \pm 5.45$ & $32.32 \pm 5.45^{\mathrm{b}}$ & $\begin{array}{c}39.20 \pm \\
22.72^{\mathrm{b}}\end{array}$ \\
\hline & NATURAL & $8.84 \pm 2.08^{\mathrm{bc}}$ & $21.87 \pm 9.75^{\mathrm{b}}$ & $1.85 \pm 0.83$ & $23.36 \pm 6.94^{\mathrm{a}}$ & $\begin{array}{c}61.06 \pm \\
10.05\end{array}$ & $23.00 \pm 10.05^{\mathrm{b}}$ & $\begin{array}{c}27.17 \pm \\
17.14^{\mathrm{a}}\end{array}$ \\
\hline & Male & $9.15 \pm 2.88^{\mathrm{b}}$ & $18.22 \pm 8.00$ & $1.67 \pm 0.99$ & $24.43 \pm 22.23$ & $\begin{array}{c}58.30 \pm \\
26.26\end{array}$ & $23.00 \pm 8.99^{\mathrm{b}}$ & $\begin{array}{c}17.25 \pm \\
11.57^{\mathrm{a}}\end{array}$ \\
\hline & Female & $5.64 \pm 3.72^{\mathrm{a}}$ & $12.69 \pm 7.28$ & $1.30 \pm 0.72$ & $16.94 \pm 11.46$ & $\begin{array}{c}41.38 \pm \\
23.91\end{array}$ & $13.77 \pm 11.52^{\mathrm{a}}$ & $\begin{array}{l}32.38 \pm \\
17.54^{\mathrm{b}}\end{array}$ \\
\hline \multirow{5}{*}{ Male } & CONTROL & $6.38 \pm 0.91^{\mathrm{a}}$ & $11.05 \pm 5.28^{\mathrm{a}}$ & $1.05 \pm 0.12$ & $11.08 \pm 8.85^{\mathrm{a}}$ & $\begin{array}{c}30.05 \pm \\
15.32^{\mathrm{a}}\end{array}$ & $18.43 \pm 3.41^{\mathrm{ab}}$ & $\begin{array}{c}21.60 \pm \\
19.49\end{array}$ \\
\hline & BUR & $6.71 \pm 0.31^{\mathrm{a}}$ & $14.11 \pm 2.68^{\mathrm{ab}}$ & $1.10 \pm 0.15$ & $18.06 \pm 3.73^{\mathrm{ab}}$ & $\begin{array}{l}68.82 \pm \\
19.27^{\mathrm{ab}}\end{array}$ & $15.50 \pm 1.71^{\mathrm{a}}$ & $11.75 \pm 4.87$ \\
\hline & URU & $9.75 \pm 2.98^{\mathrm{ab}}$ & $14.91 \pm 6.81^{\mathrm{ab}}$ & $1.42 \pm 0.96$ & $19.17 \pm 2.47^{\mathrm{ab}}$ & $\begin{array}{l}46.17 \pm \\
13.96^{\mathrm{ab}}\end{array}$ & $\begin{array}{c}20.05 \pm \\
11.69^{\mathrm{ab}}\end{array}$ & $\begin{array}{c}18.33 \pm \\
13.77\end{array}$ \\
\hline & ASTX & $12.42 \pm 2.43^{b}$ & $20.72 \pm 1.20^{\mathrm{ab}}$ & $2.61 \pm 1.72$ & $53.03 \pm 40.75^{\mathrm{b}}$ & $\begin{array}{l}67.10 \pm \\
17.00^{\mathrm{ab}}\end{array}$ & $31.06 \pm 3.93^{\mathrm{b}}$ & $\begin{array}{c}19.91 \pm \\
12.04\end{array}$ \\
\hline & NATURAL & $10.48 \pm 1.63^{\mathrm{b}}$ & $30.30 \pm 4.20^{\mathrm{b}}$ & $1.71 \pm 1.65$ & $20.81 \pm 9.22^{\mathrm{ab}}$ & $\begin{array}{l}79.35 \pm \\
38.50^{\mathrm{b}}\end{array}$ & $29.92 \pm 10.03^{b}$ & $\begin{array}{c}14.66 \pm \\
10.09\end{array}$ \\
\hline \multirow{5}{*}{ Female } & CONTROL & $3.41 \pm 1.64^{\mathrm{a}}$ & $5.64 \pm 5.49^{\mathrm{a}}$ & $1.16 \pm 0.54$ & $7.25 \pm 5.80^{\mathrm{a}}$ & $\begin{array}{l}36.64 \pm \\
26.19\end{array}$ & $5.27 \pm 2.94^{\mathrm{a}}$ & $\begin{array}{l}20.21 \pm \\
13.92^{\mathrm{a}}\end{array}$ \\
\hline & BUR & $3.41 \pm 1.39^{\mathrm{a}}$ & $9.10 \pm 2.90^{\mathrm{ab}}$ & $1.09 \pm 0.49$ & $8.54 \pm 0.82^{\mathrm{a}}$ & $\begin{array}{c}32.79 \pm \\
14.87\end{array}$ & $7.24 \pm 3.75^{\mathrm{a}}$ & $\begin{array}{c}21.44 \pm \\
4.32^{\mathrm{ab}}\end{array}$ \\
\hline & URU & $2.72 \pm 0.71^{\mathrm{a}}$ & $10.71 \pm 3.31^{\mathrm{ab}}$ & $1.58 \pm 0.23$ & $10.34 \pm 8.13^{\mathrm{a}}$ & $42.54 \pm 5.34$ & $6.67 \pm 1.63^{\mathrm{a}}$ & $\begin{array}{l}22.04 \pm \\
9.29^{\mathrm{ab}}\end{array}$ \\
\hline & ASTX & $11.46 \pm 3.09^{c}$ & $24.57 \pm 1.44^{\mathrm{c}}$ & $1.68 \pm 0.29$ & $32.64 \pm 0.52^{\mathrm{b}}$ & $\begin{array}{c}52.12 \pm \\
50.31\end{array}$ & $33.58 \pm 7.36^{\mathrm{c}}$ & $58.49 \pm 5.49^{c}$ \\
\hline & NATURAL & $7.19 \pm 0.21^{\mathrm{b}}$ & $13.44 \pm 2.57^{\mathrm{b}}$ & $1.98 \pm 1.10$ & $25.90 \pm 3.99^{b}$ & $\begin{array}{c}42.78 \pm \\
14.52\end{array}$ & $16.03 \pm 2.51^{\mathrm{b}}$ & $\begin{array}{l}39.68 \pm \\
12.76^{\mathrm{b}}\end{array}$ \\
\hline \multirow{3}{*}{ Tissue } & Total & $7.39 \pm 3.72^{\mathrm{B}}$ & $15.46 \pm 8.02^{\mathrm{C}}$ & $1.49 \pm .87^{\mathrm{A}}$ & $20.68 \pm 17.79^{\mathrm{CD}}$ & $\begin{array}{l}40.84 \pm \\
2.27^{\mathrm{G}}\end{array}$ & $\begin{array}{l}18.39 \pm \\
11.19^{\mathrm{DE}}\end{array}$ & $\begin{array}{l}24.82 \pm \\
16.50^{\mathrm{EF}}\end{array}$ \\
\hline & Male & $9.15 \pm 2.88^{\mathrm{B}}$ & $18.22 \pm 8.00^{\mathrm{CD}}$ & $\begin{array}{c}1.67 \\
\pm 0.99^{\mathrm{A}}\end{array}$ & $24.43 \pm 22.23^{\mathrm{CDE}}$ & $\begin{array}{l}56.00 \pm \\
26.55^{\mathrm{G}}\end{array}$ & $22.3 \pm 8.99^{\mathrm{F}}$ & $\begin{array}{l}17.25 \pm \\
11.57^{\mathrm{C}}\end{array}$ \\
\hline & Female & $5.4 \pm 3.72^{\mathrm{B}}$ & $12.69 \pm 7.28^{\mathrm{C}}$ & $1.30 \pm 0.72^{\mathrm{A}}$ & $16.94 \pm 11.46^{\mathrm{DE}}$ & $41.38 \pm 23.90^{\mathrm{F}}$ & $13.77 \pm 11.52^{\mathrm{CD}}$ & $32.38 \pm 17.54^{\mathrm{F}}$ \\
\hline
\end{tabular}

Different lowercase letters in the same column show significant differences $(\mathrm{p}<0.05)$ by Duncan's test and different uppercase letters in the same line show significant differences ( $\mathrm{p}$ $<0.05$ ) by Friedman's test. CONTROL = no pigment added, BUR = buriti extract, URU = annatto extract, ASTX = synthetic astaxanthin, NATURAL $=$ wild diet. 
Table 2A. Measured Color (mean and standard deviation) in Macrobrachium amazonicum fed with different sources of carotenoid pigments

\begin{tabular}{|c|c|c|c|c|}
\hline \multicolumn{2}{|c|}{ Groups } & \multicolumn{3}{|c|}{ Color space } \\
\hline & & $L^{*}$ & $\mathrm{C}^{*}$ & $\mathrm{~h}$ \\
\hline \multirow{7}{*}{ Total } & CONT & $53.20 \pm 9.32$ & $25.39 \pm 5.12$ & $52.25 \pm 9.85$ \\
\hline & BUR & $67.36 \pm 23.18$ & $28.00 \pm 11.58$ & $67.98 \pm 20.25$ \\
\hline & URU & $57.21 \pm 19.25$ & $25.53 \pm 9.08$ & $56.79 \pm 18.78$ \\
\hline & ASTX & $61.82 \pm 18.04$ & $30.79 \pm 9.09$ & $59.82 \pm 17.12$ \\
\hline & NATURAL & $82.14 \pm 31.66$ & $38.04 \pm 17.75$ & $80.41 \pm 31.41$ \\
\hline & Male & $69.71 \pm 29.64$ & $34.94 \pm 13.80^{b}$ & $67.30 \pm 29.02$ \\
\hline & Female & $58.98 \pm 10.32$ & $24.14 \pm 4.79^{\mathrm{a}}$ & $59.60 \pm 10.05$ \\
\hline \multirow{5}{*}{ Male } & CONT & $51.29 \pm 11.37$ & $28.30 \pm 5.33$ & $47.99 \pm 9.44$ \\
\hline & BUR & $77.74 \pm 31.24$ & $34.35 \pm 14.43$ & $75.81 \pm 28.01$ \\
\hline & URU & $53.52 \pm 28.13$ & $29.40 \pm 11.95$ & $51.05 \pm 27.25$ \\
\hline & ASTX & $71.43 \pm 22.28$ & $36.94 \pm 9.09$ & $68.64 \pm 21.19$ \\
\hline & NATURAL & $94.56 \pm 42.77$ & $45.71 \pm 24.05$ & $93.00 \pm 42.08$ \\
\hline \multirow{5}{*}{ Female } & CONT & $55.10 \pm 8.77$ & $22.48 \pm 3.43$ & $56.51 \pm 9.94$ \\
\hline & BUR & $56.98 \pm 6.67$ & $21.66 \pm 2.48$ & $60.16 \pm 7.58$ \\
\hline & URU & $60.91 \pm 9.71$ & $21.65 \pm 4.30$ & $62.54 \pm 6.32$ \\
\hline & ASTX & $52.21 \pm 6.29$ & $24.64 \pm 3.23$ & $51.00 \pm 7.10$ \\
\hline & NATURAL & $69.72 \pm 14.64$ & $30.37 \pm 5.70$ & $67.82 \pm 14.84$ \\
\hline
\end{tabular}

Different letters in the same column demonstrate significant differences ( $\mathrm{p}<0.05)$ using the Kruskal-Wallis test. CONTROL $=$ no pigment added, BUR $=$ buriti extract, URU = annatto extract, ASTX = synthetic astaxanthin, NATURAL = wild diet.

\section{Copyright Disclaimer}

Copyright for this article is retained by the author(s), with first publication rights granted to the journal.

This is an open-access article distributed under the terms and conditions of the Creative Commons Attribution license (http://creativecommons.org/licenses/by/4.0/). 